\title{
OS TRAJES DE MARIA OLÍMPIA: MODA E ADMIRAÇÃO PÚBLICA EM "A SENHORA DO GALVÃO"
}

\section{BRUNA DA SILVA NUNES}

Universidade Federal do Rio Grande do Sul

Porto Alegre, Rio Grande do Sul, Brasil

Resumo: Este artigo tem por objetivo realizar uma leitura do conto "A senhora do Galvão" a partir das referências e representações da moda e do vestuário encontradas no texto, e também da maneira como o anseio pela admiração pública influencia o comportamento da protagonista Maria Olímpia. Para tanto, é levada em consideração a relação de interdependência entre tais temas, observando como o suspense do enredo é deslocado da infidelidade de Galvão para a construção do comportamento de Maria Olímpia por meio da moda, do vestuário e da aparência. Como fonte de pesquisa sobre a moda oitocentista foi estudado, além de trabalhos teóricos sobre o assunto, o periódico Jornal das Senhoras, veiculado no Brasil entre os anos de 1852 e 1855.

Palavras-chave: "A senhora do Galvão"; Machado de Assis; moda; vestuário; admiração pública

\section{THE CLOTHES OF MARIA OLÍMPIA: FASHION AND PUBLIC ADMIRATION IN "A SENHORA DO GALVÃO"}

Abstract: This article aims at a reading of the short story "A senhora do Galvão" based on the references and representations of fashion and clothing found in the text. It also considers how the desire for public admiration influences the behavior of the protagonist, Maria Olimpia. Bearing this in mind, consideration is given to the interdependent relationship between these topics while observing how the plot's suspense is displaced from Galvão's infidelity to the construction of Maria Olimpia's behavior through fashion, clothing and appearance. In addition to theoretical works on eighteenth century fashion, the newspaper Jornal das Senhoras, published in Brazil between 1852 and 1855 was studied as a source of research on this subject.

Keywords: "A senhora do Galvão"; Machado de Assis; fashion; clothing; public admiration 


\section{Moda, vestuário e prosa machadiana}

$\frac{1}{1}$

recorrente na obra de Machado de Assis o fato de o vestuário das personagens desempenhar função relevante na construção narrativa.

Como exemplos significativos, temos os vestidos que exaltam a beleza de Sofia em Quincas Borba, a farda de alferes que se tornou a alma exterior de Jacobina no conto "O espelho" ou os sapatos de duraque que denunciam a classe social de Capitu em Dom Casmurro. Além desses, diversos outros contos, romances e crônicas apresentam a indumentária e a moda como elementos importantes da elaboração ficcional.

Levando isso em consideração, realço que a moda é baseada em paradoxos, pois a vestimenta tanto pode ajudar a entender a ideologia dominante de uma época quanto a desvendar os traços subjetivos de seu portador; pode ser a indicação para localizar o espaço geográfico que determinada pessoa ocupa, bem como seu ânimo e seu temperamento. Pensando em como essa dinâmica se dá na análise literária, a representação da moda e do vestuário auxilia a inserir o leitor no contexto sócio-histórico da obra ao mesmo tempo que tem o poder de contribuir para a constituição das personagens e, por extensão, da trama como um todo.

É importante marcar que os termos "moda" e "vestuário" nem sempre se equivalem, pois enquanto o vestuário se refere a tudo aquilo que o ser humano veste, a moda, em um conceito amplo, diz respeito a um fenômeno social de mudança cíclica dos costumes, à aceleração de produção, ao desejo de novidade, às transformações regulares nos diversos setores da vida social. ${ }^{1}$ Neste trabalho, lanço mão de um conceito de moda mais restrito, explorado por Gilda de Mello e Souza, "reservado às mudanças periódicas nos estilos de vestimenta e nos demais detalhes da ornamentação pessoal". ${ }^{2}$ Avaliando esses conceitos, entendo que a ocorrência de uma representação do vestuário pode trazer conteúdo de moda ou não.

Posto isso, este artigo propõe uma reflexão acerca da representação da moda e do vestuário no conto "A senhora do Galvão", analisando qual a relevância que esses temas adquirem na narrativa e como eles influenciam o desenvolvimento do enredo, tendo como foco a personagem Maria Olímpia.

\footnotetext{
${ }^{1}$ Síntese composta a partir das leituras de SOUZA, O espírito das roupas (1987), CALANCA, História social da moda (2011), VIANA, "O Imperador nunca esteve nu" (2012) e LIPOVETSKY, O império do efêmero: a moda e seu destino nas sociedades modernas (2013).

${ }^{2}$ SOUZA, O espírito das roupas: moda no século XIX, p. 19.
} 
Como aparato teórico, destaco, além da já citada obra de Gilda de Mello e Souza (1987), os trabalhos de Mariana Rodrigues, Mancebos e mocinhas: moda na literatura brasileira do século XIX (2010); de Diana Crane, A moda e seu papel social: classe, gênero e identidade das roupas (2006); e de Georg Simmel, "A moda" (2008).

\section{Entre cartas, xales e bailes: Maria Olímpia e a moda no oitocentos brasileiro}

O conto "A senhora do Galvão" foi publicado por Machado de Assis em 14 de maio de 1884 na Gazeta de Notícias e incluído, ainda em 1884, na coletânea Histórias sem data, praticamente sem alterações. ${ }^{3}$ Narrado em terceira pessoa, o enredo do conto centra-se no recebimento, por parte de Maria Olímpia, de cartas anônimas que denunciavam o adultério de seu marido, o advogado Eduardo Galvão. De acordo com as cartas, Galvão estaria traindo Maria Olímpia com uma das melhores amigas dela, a Ipiranga, viúva do brigadeiro.

É interessante reparar que essas informações e a confirmação do adultério ocorrem logo no primeiro parágrafo do texto, eliminando qualquer possibilidade de suspense nesse sentido. "Começaram a rosnar dos amores deste advogado com a viúva do brigadeiro, quando eles não tinham ainda passado dos primeiros obséquios."

Dessa forma, como ressalta Jaison Crestani, "com a eliminação do suspense, a trama em si perde o interesse e a ênfase da narrativa passa para a análise do comportamento da personagem". ${ }^{5}$ Entretanto, acredito que seja possível usar o termo "deslocamento de suspense", e não "eliminação", pois a atenção da narrativa deixa de estar no adultério e se desloca para o modo como Maria Olímpia reage diante de tal situação. Sendo assim, a partir dessa "descentralização do enredo", termo empregado por Crestani, temáticas

\footnotetext{
${ }^{3}$ Conforme nota presente na edição eletrônica de Histórias sem data disponibilizada no site Machado de Assis.net (<www.machadodeassis.net>), ao ser publicado na Gazeta de Notícias, a única mudança feita no texto do conto do jornal para o livro foi no trecho "no bolso do vestido". Nas duas primeiras edições em livro tal trecho foi substituído por "no vestido".

${ }^{4}$ ASSIS, Histórias sem data, p. 277, grifo meu.

5 CRESTANI, "A senhora do Galvão eliminou a mulher: estudo sobre um conto de Machado de Assis", p. 5 .
} 
relacionadas à moda, ao vestuário e à aparência se farão presentes, tornandose referências fundamentais para o desenrolar da trama.

No primeiro bilhete recebido por Maria Olímpia, temos os seguintes dizeres: "não é possível que a senhora se deixe embair mais tempo, tão escandalosamente, por uma de suas amigas, que se consola da viuvez, seduzindo os maridos alheios, quando bastava conservar os cachos...". 6 Tendo feito a transcrição do bilhete, o narrador retoma a palavra com estes termos: "que cachos? Maria Olímpia não perguntou que cachos eram; eram da viúva do brigadeiro, que os trazia por gosto, e não por moda. Creio que isto se passou em 1853".?

No trecho de "A senhora do Galvão" supracitado, o ponto focal são os cabelos, que, assim como as roupas, sofreram diversas modificações ao longo do século XIX. No decorrer do século, a moda feminina, ao contrário da masculina, passou por um processo de complexificação, tendo mudanças periódicas nas cores, tecidos e principalmente na forma. Com isso, os trajes das mulheres se prestavam, de maneira mais acentuada do que o dos homens, a um papel de submissão às regras sociais e de diferenciação de classe, auxiliando a nutrir o capitalismo através da obsessão por adequação. Como afirma Diana Crane, "no século XIX e início do século XX, o sistema da moda produziu estilos de roupa que expressavam a posição social das mulheres que as vestiam, ou aquela à qual aspiravam". ${ }^{8}$

Quanto aos cabelos, era de bom tom que as mulheres os mantivessem presos e cobertos quando em público; contudo, mesmo dentro desse código restrito de boa conduta foram surgindo variações. Inicialmente, o cabelo era todo escondido, fosse por chapéus, turbantes ou mantilhas; já a partir de 1830 começaram a aparecer penteados elaborados, ora em coque, ora em formato de cascata, presos de diferentes formas. Entretanto, como aponta Mariana Rodrigues, uma característica era comum: "a importância de uma cabeleira é crucial para a identidade feminina no século XIX. [...] Só madeixas longas, volumosas, macias e perfumadas são dignas de nota". ${ }^{9}$ Em vista disso, a viúva, com seus cabelos cacheados, dispunha de um atrativo importantíssimo que pode ter sido um dos fatores para que Galvão se interessasse por ela.

\footnotetext{
${ }^{6}$ ASSIS, cit., p. 277.

${ }^{7}$ Idem, p. 278.

${ }^{8}$ CRANE, A moda e seu papel social: classe, gênero e identidade das roupas, p. 272.

${ }^{9}$ RODRIGUES, Mancebos e mocinhas: moda na literatura brasileira do século XIX, p. 143.
} 
No momento posterior ao recebimento da carta, Maria Olímpia decide escolher xales, adorno que estava em voga nos anos de 1850 e que servia para esconder a cintura, pudor imposto às mulheres da época. Como ocorria com grande parte das modas que surgiam na França, usá-los era quase uma obrigatoriedade para as mulheres da elite brasileira, que sentiam necessidade de se aproximarem dos paradigmas europeus.

Segundo Souza (1987), no que concerne ao estudo da moda, o século XIX possui, de certo modo, uma vantagem em relação aos anteriores, pois podemos analisar as vestimentas não somente por meio de pinturas ou desenhos, mas também recorrendo à fotografia e às pranchas coloridas de moda. Além desses recursos, aponto a importância dos periódicos de moda para se pesquisar a moda oitocentista. No Jornal das Senhoras, folha que circulou no Brasil entre os anos de 1852 e 1855, época concomitante àquela na qual o conto se passa, encontramos na seção "Modas" diversas referências aos xales; na edição do dia 8 de agosto de 1852, a seção é dedicada a fornecer informações sobre a aplicação dos xales, sendo o trajar das mulheres parisienses colocado como o modelo a ser seguido.

Que as mantas e os xales estão de novo inscritos na lista dos elegantes do toilette do bom-tom, é fora de toda dúvida: os últimos manteletes, chamados manteletes-xales, já revelavam a proximidade dessa transição da moda, cuja necessidade fazia sentir-se há muito. Não obstante, as elegantes parisienses ainda trajam o mantelete-xale, mas o empregam somente em certos casos em que se casa bem a ocasião com o toilette acompanhado de tal adorno. O trajar grave requer um xale, e as mantas substituem o mantelete, uma vez que o vestido é afogado. ${ }^{10}$

Essas exigências em relação às vestimentas impostas ao público feminino parecem ser mais uma forma de mantê-lo alienado de seu contexto histórico-social: ao invés de se preocuparem com assuntos como trabalho ou política, as mulheres fixavam suas atenções nas revistas de moda e nos romances de folhetim. Enxergamos isso de maneira mais clara se compararmos a moda feminina com a masculina. Diferentemente do que ocorria antes, no século XIX os homens se afastaram do mundo da moda. Esse afastamento ocorreu, como destaca Souza (1987), principalmente por conta da Revolução Francesa, pois, com os novos ideais de igualdade, a

${ }^{10}$ Jornal das Senhoras, 8 ago. 1852, p. 42. 
aristocracia não era mais a única camada que possuía destaque no processo social, e fatores como talento e competência também passaram a ser avaliados além da questão financeira ou tradição familiar. Desse modo, o sexo masculino voltou suas atenções para a carreira, desviando seu interesse da moda. No Brasil, essa dinâmica ocorreu mais brandamente por conta do desenvolvimento tardio da burguesia; então, em vez de ser suscitada pelas condições de produção, foi mais influenciada por uma dependência cultural em relação à Europa.

A autora indica que "o homem só se desinteressou da vestimenta quando esta, devido à mudança profunda no curso da história, deixou de ter importância excessiva na competição social". ${ }^{11}$ Assim, a roupa masculina perde sua função ornamental, transformando-se praticamente em um uniforme, preto $^{12}$ e composto por calça, camisa, colete e casaca/paletó/sobrecasaca. Esse desligamento da moda, no entanto, não foi completo, dado que os homens pertencentes à elite encontraram outras formas de manifestar refinamento e de se afirmar socialmente sem comprometer suas vestes padronizadas, privilegiando a exploração estética do rosto e "o domínio de certas insígnias de poder e erotismo, como os chapéus, as bengalas, os charutos e as joias".13

Se por um lado a moda deixa de ser um campo expressivo de competição social para o homem, para a mulher ela se configura como um dos poucos espaços de agência. Nesse sentido, vemos representada em "A senhora do Galvão" uma competição feminina enfatizada por questões relacionadas ao vestuário, como verificamos no próximo excerto:

Maria Olímpia pegou no xale que a mucama lhe dava e foi pô-lo aos ombros, defronte do espelho. Achou que lhe ficava bem, muito melhor que à viúva. Cotejou as suas graças com as da outra. Nem os olhos nem a boca eram comparáveis; a viúva tinha os ombros estreitinhos, a cabeça grande, e o andar feio. Era alta; mas que tinha ser alta? E os trinta e cinco anos de idade, mais nove que ela? ${ }^{14}$

\footnotetext{
${ }^{11}$ SOUZA, cit., p. 80.

12 Marcelo de Araújo (2012) apresenta várias possíveis razões para a escolha da cor preta; uma delas é a circunstância de os centros urbanos estarem, em virtude da Revolução Industrial, repletos de fuligem, e as colorações escuras ajudariam a esconder a sujeira. Outro motivo é que o preto começava a evocar seriedade e compostura, pois se contrapunha a uma vaidade que o colorido poderia sugerir.

${ }^{13}$ SOUZA, cit., p. 75.

${ }^{14}$ ASSIS, cit., p. 278.
} 
A competição era algo constante na área urbana devido ao maior número de pessoas e à maior integração entre as classes. Primeiramente ela ocorria em grupos fechados, dentro da mesma classe social; no entanto, devido às especulações da indústria - que permitiu que, mesmo de forma restrita, outras classes tivessem acesso à moda -, com o passar do século essa competição irá se alastrar, fazendo com que as mulheres se preocupem cada vez mais com a escolha das roupas e acessórios. Pelo que nos mostra o narrador, Maria Olímpia não fugia desse estereótipo.

Maria Olímpia tinha a vocação da vida exterior, e, nas procissões e missas cantadas, gostava principalmente do rumor, da pompa; a devoção era sincera, tíbia e distraída. A primeira coisa que ela via na tribuna das igrejas, era a si mesma. Tinha um gosto particular em olhar de cima para baixo, fitar a multidão das mulheres ajoelhadas ou sentadas, e os rapazes, que, por baixo do coro ou nas portas laterais, temperavam com atitudes namoradas as cerimônias latinas. Não entendia os sermões; o resto, porém, orquestra, canto, flores, luzes, sanefas, ouros, gentes, tudo exercia nela um singular feitiço. ${ }^{15}$

No mesmo dia em que recebeu a primeira carta, Maria Olímpia e o marido foram ao teatro - a compra dos bilhetes foi o motivo dado por Galvão para ter se atrasado naquela mesma tarde. Acerca da importância do teatro no século XIX, trago as palavras de Rodrigues:

[...] o teatro afirmou-se no século XIX do carioca como um local e um momento oportunos para o jogo de expansão amorosa burguesa, onde a exibição do indivíduo podia proporcionar-lhe um valor de troca adequado aos seus atributos físicos, naturais ou construídos, aumentando seu prestígio no mercado dos relacionamentos. Toaletes custosas, joias e modos refinados são as cartas do baralho feito de damas e valetes. ${ }^{16}$

Fazendo um deslocamento da citação acima para a situação apresentada no conto, percebemos que, apesar de casada, Maria Olímpia não

${ }^{15}$ Idem, p. 280.

${ }^{16}$ RODRIGUES, cit., p. 187. 
descuidava da aparência e desejava ser contemplada pela sociedade. Isso é visível na cena da entrada do casal no teatro:

[...] quem é que estava no camarote contíguo ao deles? Justamente a viúva e a mãe. Esta coincidência, filha do acaso, podia fazer crer algum ajuste prévio. Maria Olímpia chegou a suspeitá-lo; mas a sensação da entrada não lhe deu tempo de examinar a suspeita. Toda a sala voltarase para vê-la, e ela bebeu, a tragos demorados, o leite da admiração pública. $^{17}$

Tal como aconteceu ao receber a carta, quando ficou escolhendo xales sem, aparentemente, dar atenção às acusações feitas ao marido e à amiga, mais uma vez a esperada preocupação com a infidelidade de Galvão é superada pela necessidade de admiração e aprovação perante a sociedade. Mais importante do que solucionar o problema conjugal era aparentar que tudo estava bem; para Maria Olímpia isso era suficiente e lhe causava satisfação, o glamour transcendia qualquer dificuldade.

[...] ela cuidou de os não perder de vista - e renovou a resolução de cinco em cinco minutos, durante meia hora, até que, não podendo fixar a atenção, deixou-a andar. Lá vai ela, inquieta, vai direito ao clarão das luzes, ao esplendor dos vestuários, um pouco à ópera, como pedindo a todas as coisas alguma sensação deleitosa em que se espreguice uma alma fria e pessoal. E volta depois à própria dona, ao seu leque, às suas luvas, aos adornos do vestido, realmente magníficos. Nos intervalos, conversando com a viúva, Maria Olímpia tinha a voz e os gestos do costume, sem cálculo, sem esforço, sem ressentimento, esquecida da carta. $^{18}$

A utilização de luvas denotava que seu portador pertencia às classes altas, pois significava distanciamento dos trabalhos manuais; além disso, no caso específico das mulheres, por uma questão de recato era indicado que, sempre que estivesse em público, o grupo feminino lançasse mão do acessório. Em relação ao uso de luvas no século XIX, Rodrigues ressalta que

\footnotetext{
${ }^{17}$ ASSIS, cit., p. 283.

${ }^{18}$ Ibidem, grifos meus.
} 
[...] usar luvas denotava nobreza de berço, educação privilegiada, distanciamento dos trabalhos manuais. Um homem de honra era um homem de luvas. Uma mulher pudica mostrava-se calçada de luvas ao interagir com desconhecidos, pois esse pequeno pedaço de tecido tinha o poder de distanciar ao intermediar o contato de mãos nuas; tinha também o poder da intimidade quando sua ausência proporcionava o toque das peles quentes. ${ }^{19}$

Quanto aos leques, seu uso era uma das maneiras de a mulher mostrar graciosidade por meio dos gestos, assinalando que não eram apenas os bens materiais que davam graça ao grupo feminino, mas também ações e atitudes como as boas maneiras, os talentos musicais, o caminhar e o sorriso. Sobre isso, Souza pontua que "à medida que as diferenças exteriores se atenuam pela generalização da moda, o indivíduo tende a revelar o seu nível 'não tanto pela fazenda, o chapéu, as joias, mas pela educação, jeito de andar, maneiras'" ${ }^{20}$ Logo, não bastava que Maria Olímpia se vestisse com os melhores e mais belos tecidos ou exibisse adornos de joalherias famosas, era necessário possuir certo encantamento que, pelo que sugere o narrador, sua amiga viúva tinha de sobra.

Juntas saíram do camarote, no fim, e atravessaram os corredores. A modéstia com que a viúva trajava podia realçar a magnificência da amiga. As feições, porém, não eram o que esta afirmou, quando ensaiava os xales de manhã. Não, senhor; eram engraçadas, e tinham um certo pico original. Os ombros proporcionais e bonitos. Não contava trinta e cinco anos, mas trinta e um. ${ }^{21}$

Uma semana após o passeio ao teatro, mais um bilhete foi enviado à Maria Olímpia, e o recebimento das cartas ocorreu durante três meses; mesmo assim, a esposa traída se recusava ou simulava não acreditar no que lhe era contado. Passado algum tempo, apesar dos vários indícios, fingia não notar as mentiras do marido, afinal, ele lhe proporcionava conforto, idas ao

\footnotetext{
${ }^{19}$ RODRIGUES, cit., p. 106.

${ }^{20}$ SOUZA, cit., p. 137. A referência do texto citado por Souza é a seguinte: DEONNA, "Art et societé: les groupes sociaux et l'art". Revue Internationale de Sociologie, 35ème année, n. 5 e 6, maio e jun. 1927, p. 262.

${ }^{21}$ ASSIS, cit., p. 284.
} 
teatro e bailes. Então ela, cada vez mais, poderia beber o "leite da admiração pública", e se sujeitava, inclusive, a manter a amizade com Ipiranga.

Verificamos, aqui, como o anseio de colocação social ultrapassava a vida íntima da personagem; mesmo quando Galvão descobriu que a esposa recebia cartas que o denunciavam, Maria Olímpia não aproveitou a oportunidade para questioná-lo, ficando feliz por não ouvir a confirmação dos fatos. Segundo Crestani, "isso colocaria em risco o seu casamento e a sua integridade social", ${ }^{22}$ visto que era importante manter a imagem de um casamento feliz e sólido.

Talvez para tentar amenizar as traições e agradar a mulher, Galvão tornou-se sócio do Cassino Fluminense, local onde eram organizados grandes eventos no Rio de Janeiro do século XIX.

No Cassino Fluminense, os bailes eram habituais. A eles iam os elegantes, sendo mesmo de bom-tom as famílias da alta roda tornaremse sócias da casa. Muitos que "achavam na vida exterior [...] a sensação de uma grande carícia pública", sempre aí iam "recolher nova cópia de admirações". ${ }^{23}$

Pouco tempo antes do primeiro baile promovido pelo Cassino em que Maria Olímpia compareceria, a personagem foi até uma loja a fim de comprar um presente de aniversário para a viúva. Lá, viu uma meia lua de diamantes para o cabelo, que logo virou seu objeto de desejo para uso no dia da festa; porém, a peça já havia sido vendida.

A intenção de comprar joias e vestidos novos para ir aos bailes era natural, dado que as festas se configuravam como o ápice da exposição da moda pois, sendo uma situação em que os membros da elite se reuniam, uma competição intraclasse acabava por ser aflorada. Portanto, estar bem trajado e exibindo adornos refinados era uma maneira de atestar poder; além disso, o baile era o momento de maior exibicionismo e irradiação do corpo feminino. Se na vida cotidiana as mulheres deveriam vestir-se com pudor, nos bailes a rigidez dos trajes era amenizada, sendo bem aceitos, por exemplo, vestidos mais decotados. As mocinhas deveriam vestir-se com maior recato, passando uma imagem de pureza, mas para as mulheres casadas era uma ótima forma de ratificar sua beleza mediante a utilização de roupas elaboradas e repletas

${ }^{22}$ CRESTANI, cit., p. 11.

${ }^{23}$ BORGES, "Em busca do Rio exterior: sociabilidade do Rio de Machado de Assis", p. 60. 
de erotismo. Nas revistas de moda da época eram comuns exemplos de indumentárias consideradas adequadas para passeios durante o dia e as próprias para baile.

No Jornal das Senhoras temos as seguintes imagens, nas quais é possível detectar as diferenças entre as roupas cotidianas para passeio, mais fechadas e com menos adornos, e o vestido de baile, que permite que o corpo fique mais à mostra, além de ser mais requintado.

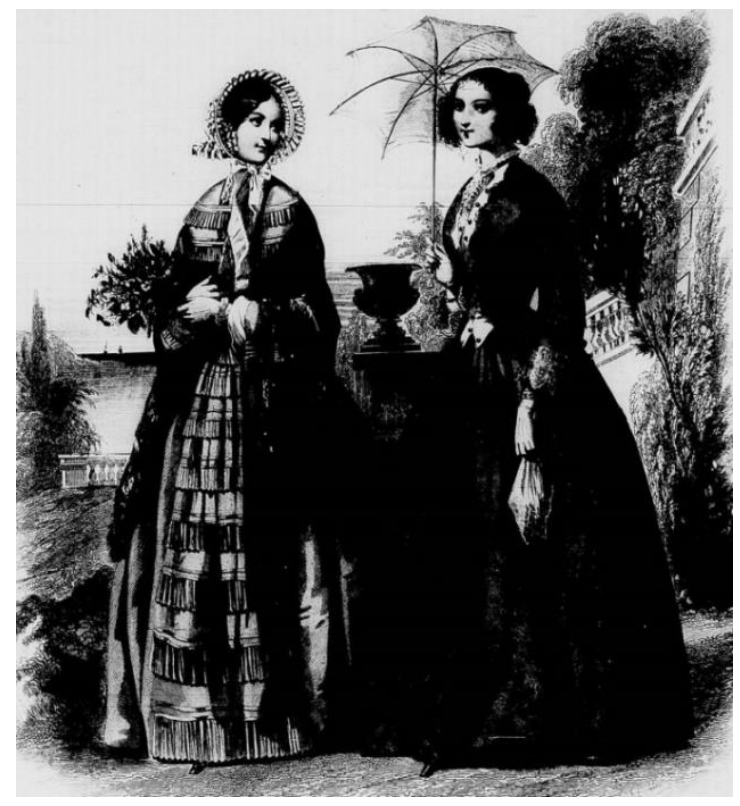

Figura 1 Trajes de passeio

Fonte: Jornal das Senhoras, 20 fev. 1853

(c) Biblioteca Nacional Digital Brasil 


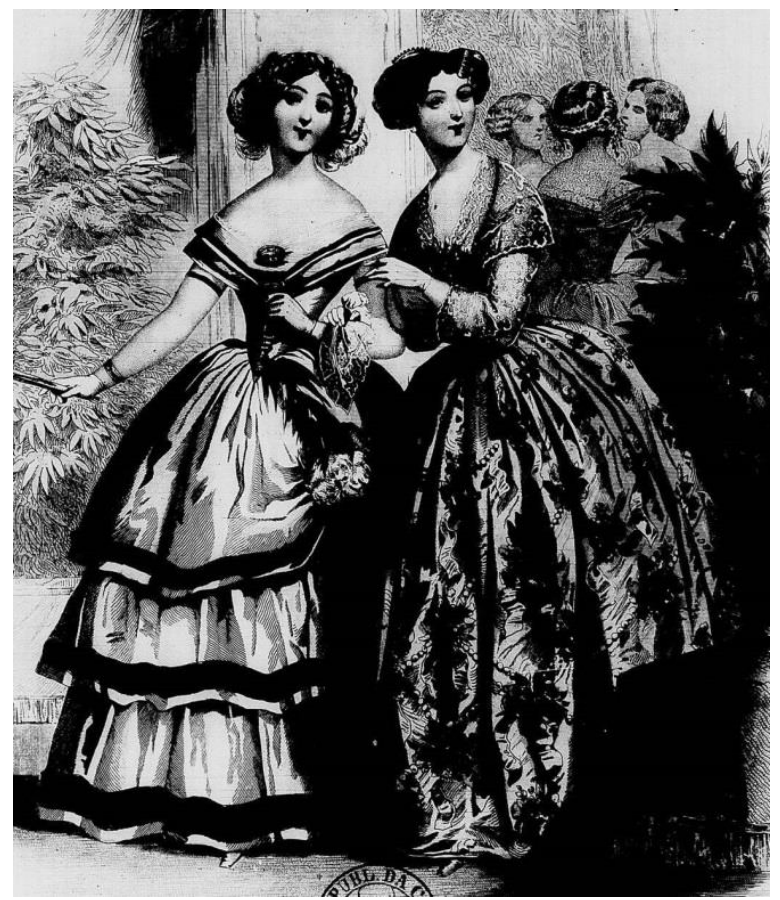

Figura 2 Trajes de baile

Fonte: Jornal das Senhoras, $1^{\circ}$ ago. 1852.

(C) Biblioteca Nacional Digital Brasil

$\mathrm{Na}$ noite do baile, Maria Olímpia entrou emocionada no Cassino Fluminense, ansiosa pelos olhares que receberia. "Pessoas que a conheceram naquele tempo, dizem que o que ela achava na vida exterior, era a sensação de uma grande carícia pública, a distância; era a sua maneira de ser amada."24 Saliento que a normatização do vestuário acarretava uma padronização das mulheres, que seguiam um estilo correspondente com a ocasião, com a idade e com a situação matrimonial. Todavia, apesar de parecer contraditório, as vestimentas eram uma das únicas maneiras que as mulheres tinham de expressar sua individualidade, ainda que dentro dos itens pré-selecionados arbitrariamente.

Pela lógica da fantasia estética, podemos pensar na moda em sua articulação com a constituição da aparência dos sujeitos, considerandose o modo como estes constroem sua individualidade, ao passo que se engajam e conformam determinadas relações de pertencimento social, medidas pelos objetos e processos comunicacionais. Paradoxal, a moda é marcada por processos de distinção e imitação, de diferenciação e

${ }^{24}$ ASSIS, cit., p. 288. 
partilha, reconhecendo-se que, ao mesmo tempo em que os sujeitos adotariam a padronização, identificando-se com uma determinada coletividade, optariam pela diferenciação, por meio das práticas e exercícios estéticos pessoais. $^{25}$

Por meio das palavras de Calza, apreendemos o caráter ambivalente da moda, compreendendo que ela atende, ao mesmo tempo, o coletivo e o individual, o desejo de inserção e de diferenciação; como aponta Simmel,

[...] a moda satisfaz uma necessidade de apoio social, ela leva o singular à via seguida por todos, ela indica uma universalidade que reduz o comportamento de cada um a mero exemplo. Ela também satisfaz, no entanto, a necessidade de distinção, a tendência à diferenciação, à variação, ao destaque. ${ }^{26}$

Ao se analisar o século XIX, essa duplicidade se torna mais aparente, uma vez que os trajes femininos tolhiam as mulheres, mas também davam protagonismo a elas. O exemplo mais evidente desse protagonismo consistia nas festas, pois o vestido feminino era o item que mais se destacava, possibilitando às mulheres uma notoriedade que não era viável em outras situações sociais. Podemos pensar, então, que o comportamento de Maria Olímpia é condicionado pelo contexto social no qual a personagem vive; logo, sua preocupação com a aparência e a necessidade de aprovação pública podem ser justificadas pelas imposições e pressões pelas quais as mulheres passavam. Sobre essa questão, Geanneti Salomon alega que

[...] podemos, portanto, perceber a diferença primordial entre o papel social masculino e o feminino na sociedade do século XIX, sendo que os homens tinham acesso a uma carreira, aos negócios, à política, ao pensamento; as mulheres podiam apenas se dedicar aos afazeres domésticos, ao cuidado da casa e dos filhos e à moda, talvez sua única forma de expressão pessoal. ${ }^{27}$

Entretanto, a esposa de Galvão não foi a única mulher a receber a atenção dos frequentadores do baile; a viúva teve, igualmente, seu momento

\footnotetext{
${ }^{25}$ CALZA, "Entre a cultura do impresso e a cultura da moda: tramas conceituais e históricas", p. 12.

${ }^{26}$ SIMMEL, "A moda", p. 165.

${ }^{27}$ SALOMON, Moda e ironia em Dom Casmurro, p. 103.
} 
de esplendor, e um dos causadores de admiração foi uma meia lua de diamantes que lhe enfeitava os cabelos, justamente a joia que Maria Olímpia almejava. Para Maria Olímpia isso era imperdoável, Ipiranga disputava com ela os olhares públicos, o que era uma falta muito mais grave do que ser amante de seu marido. Seguem as frases que terminam o conto:

- Hoje quase não tenho tido tempo de estar com você - disse ela a Maria Olímpia, perto de meia-noite.

- Naturalmente - disse a outra abrindo e fechando o leque; e, depois de umedecer os lábios, como para chamar a eles todo o veneno que tinha no coração: - Ipiranga, você está hoje uma viúva deliciosa... Vem seduzir mais algum marido?

A viúva empalideceu, e não pôde dizer nada. Maria Olímpia acrescentou, com os olhos, alguma coisa que a humilhasse bem, que lhe respingasse lama no triunfo. Já no resto da noite falaram pouco; três dias depois romperam para nunca mais. ${ }^{28}$

Nesse final temos a confirmação de que Maria Olímpia colocava a vida exterior em primeiro plano, pois sua reação comprova o quanto ela, enquanto indivíduo, estava assimilada por uma sociedade cujos valores eram, em muitos casos, calcados na supervalorização da aparência. Para Maria Olímpia, o marido era possivelmente uma porta para entrar no circuito da elite fluminense, uma necessidade social, enquanto o olhar do público era sua fonte de prazer, "uma carícia" pública. Quando Ipiranga ataca esse outro "marido", Olímpia sente-se traída e reage.

\section{Senhora do Galvão?}

Para melhor entender o mecanismo social subjacente aos eventos representados no conto, vale retomar que, apesar de se distanciarem do mundo da moda, os homens não se isolaram dele, encontrando outros meios de ostentar seu poder. Além das já citadas insígnias de poder, aos homens existia mais uma possibilidade de comprovar seu triunfo, qual seja, a "publicação" de suas esposas. Maria Alice La Serra aponta que "o próspero homem de negócios transfere para a mulher vestida o dever de ressaltar suas

${ }^{28}$ ASSIS, cit., p. $289-290$. 
riquezas e poder, como se fosse uma vitrine". ${ }^{29}$ O papel da mulher dentro desse mundo era o de um ser submisso, que servia para gerar filhos e enfeitar a casa. Se solteiras, deveriam vestir-se com o intuito de, por meio das roupas, atestarem suas qualidades; se casadas, tinham o papel de através de seus trajes manifestarem o sucesso de seus maridos. Mesmo no que concerne à moda, campo no qual o grupo feminino teria mais autonomia, o gosto da mulher é limitado a todo instante, obrigando-a a se uniformizar e a lidar com restrições. Em História social da moda, Daniela Calanca aborda esse tema, contrapondo os papéis feminino e masculino na sociedade oitocentista.

Que a beleza, e não o intelecto, é a arma para se tornar "alguém", as mulheres já o sabem há tempos. Mas esse conhecimento assume conotações de certeza definitiva ao longo do século XIX, quando a afirmação da sociedade burguesa consegue fixar papéis rigidamente separados para os homens e para as mulheres. O próprio modo de se vestir espelha essa rígida divisão. Passando dos salões para o escritório e a loja, os homens abandonam as fantasias da moda, que até aquele momento tinham escrupulosamente seguido, para assumir um vestuário sóbrio, de origem inglesa. As mulheres, por sua vez, permanecem entre as paredes domésticas, que sua presença deve absolutamente embelezar para tornar feliz o chefe da casa, e acentuar a atenção no seu corpo e na sua beleza. O problema do vestuário, visto tanto como instrumento de sedução como símbolo de status, continua por todo século XIX a ser uma questão central no universo feminino, diferente do que ocorre com os homens, para quem a simplicidade e a praticidade tornaram-se há tempos exigências estéticas primárias. Contemporaneamente, são acrescentadas ao papel da mulher outras prerrogativas. Além de agradar o homem, a mulher deve ser também uma boa companheira, uma boa mulher e uma mãe perfeita. Assumindo esses novos papéis, a mulher torna-se a "rainha do lar"; e no total conformismo com as normas da boa sociedade e da boa aparência pode-se identificar a razão pela qual as senhoras das classes altas continuam a se angustiar por seu corpo e vestuário [...]. ${ }^{30}$

No argumento de Calanca, fica claro o quanto a referida angústia feminina no tocante ao vestuário ocorre por conta do ideal de mulher

${ }^{29}$ LA SERRA, Corpo e roupa: território da existência e da cultura: reflexões para o redesenho do corpo feminino no século XIX, p. 16.

30 CALANCA, História social da moda, p. 98. 
perfeita difundido no século XIX, ideal que tolhia as mulheres e as tornava submissas dentro de um sistema de origem patriarcal, no qual as ações femininas eram pautadas em relação aos desejos do homem. No entanto, pensando em "A senhora do Galvão" e em uma possível dialética entre processo social e forma literária, se por um lado a importância dada por Maria Olímpia à sua vida pública e à sua aparência pode ser interpretada como um atestado da subordinação (mesmo involuntária) das mulheres aos ditames da moda e às regras de comportamento, por outro pode denotar emancipação. Ao ignorar o adultério do marido e dirigir as atenções para ela própria, a personagem demonstra independência, buscando em elementos fora do casamento, como a moda, satisfação e realização pessoal.

A partir da análise do conto, é possível pensar, portanto, na diversidade de sentidos que o título da trama pode assumir. O primeiro seria o do apagamento de Maria Olímpia, sendo a personagem reduzida ao seu papel na sociedade oitocentista, ou seja, a esposa. Por outro lado, o "senhora", que pode denotar subalternidade, também pode significar o contrário. Por mais que, supostamente, seja Galvão que detenha a posição de poder por conta dos privilégios masculinos no século XIX, Maria Olímpia, ao dirigir suas atenções para interesses pessoais, inverte a lógica patriarcal. Desse modo, Maria Olímpia se torna a senhora da relação, a senhora do Galvão, senhora de si mesma.

\section{Referências}

ARAÚJO, Marcelo de. Dom Pedro II e a moda masculina na época vitoriana. São Paulo: Estação das Letras e Cores, 2012.

ASSIS, Machado de. Histórias sem data. São Paulo: W. M. Jackson, 1957.

BORGES, Valdeci Rezende. "Em busca do Rio exterior: sociabilidade do Rio de Machado de Assis". Estudos históricos. Rio de Janeiro, v. 2, n. 28, 2001. Disponível em: http://bibliotecadigital.fgv.br/ojs/index.php/reh/article/download/2143/1282. Acesso em: 22 nov. 2015.

CALANCA, Daniela. História social da moda. 2. ed. Tradução de Renato Ambrosio. São Paulo: Editora Senac São Paulo, 2011.

CALZA, Márlon Uliana. "Entre a cultura do impresso e a cultura da moda: tramas conceituais e históricas". Congresso Brasileiro de Ciências da Comunicação Intercom, 35, 2012, Fortaleza. Anais... Disponível em: 
http://www.intercom.org.br/sis/2012/resumos/R7-2096-1.pdf. Acesso em: 20 abr. 2015.

CRANE, Diana. A moda e seu papel social: classe, gênero e identidade das roupas. Tradução de Cristiana Coimbra. São Paulo: Editora Senac São Paulo, 2006.

CRESTANI, Jaison Luís. "A senhora do Galvão eliminou a mulher: a duplicidade feminina em um conto de Machado de Assis". Terra Roxa e Outras Terras: Revista de Estudos Literários, Londrina, v. 13, out. 2008. Disponível em: http://www.uel.br/pos/letras/terraroxa/g_pdf/voll3/TRvoll3a.pdf. Acesso em: 20 ago. 2016.

LA SERRA, Maria Alice Ximenes dos Santos. Corpo e roupa: território da existência e da cultura: reflexões para o redesenho do corpo feminino no século XIX. 2004. 118f. Dissertação (Mestrado em Artes) - Instituto de Artes, Universidade Estadual de Campinas. Campinas, 2004.

LIPOVETSKY, Gilles. O império do efêmero: a moda e seu destino nas sociedades modernas. Tradução de Maria Lucia Machado. São Paulo: Companhia das Letras, 2009.

O JORNAL das Senhoras: Modas, Litteratura, Bellas-Artes, Theatros e Critica, Rio de Janeiro, 1852 - 1853.

RODRIGUES, Mariana Christina de Faria Tavares. Mancebos e mocinhas: moda na literatura brasileira do século XIX. São Paulo: Estação das Letras e Cores, 2010.

SALOMON, Geanneti Tavares. Moda e ironia em Dom Casmurro. São Paulo: Alameda, 2010.

SIMMEL, Georg. "A moda". Iara: Revista de Moda, Cultura e Arte, São Paulo, v. 1, n. 1, abr./ago. 2008. Disponível em: http://wwwl.sp.senac.br/hotsites/blogs/revistaiara/wpcontent/uploads/2015/01/07_IARA_Simmel_versao-final.pdf. Acesso em: 2 out. 2016.

SOUZA, Gilda de Mello e. O espírito das roupas. São Paulo: Companhia das Letras, 1987.

VIANA, Fausto. "O Imperador nunca esteve nu". In: ARAÚJO, Marcelo de. Dom Pedro II e a moda masculina na época vitoriana. São Paulo: Estação das Letras e Cores, 2012. 
BRUNA DA SILVA NUNES é mestra em Literatura Brasileira pela Universidade Federal do Rio Grande do Sul (UFRGS) e doutoranda em Estudos de Literatura pela mesma instituição. E-mail: bsnunes91@gmail.com.

Recebido: 28.10 .16

Aprovado: 23.01.17 